Published in final edited form as:

Anal Chem. 2019 June 04; 91(11): 7403-7410. doi:10.1021/acs.analchem.9b01351.

\title{
Quantitation of Apurinic/Apyrimidinic Sites in Isolated DNA and in Mammalian Tissue with Reduced Artifact
}

\author{
Haoqing Chen ${ }^{\dagger}$, Lihua $\mathrm{Yao}^{\dagger}$, Christina Brown ${ }^{\dagger}$, Carmelo J. Rizzo ${ }^{\ddagger}$, Robert J. Turesky ${ }^{\dagger},{ }^{*}$ \\ †Masonic Cancer Center and Department of Medicinal Chemistry, University of Minnesota, \\ Minneapolis, Minnesota, 55455, United States \\ ¥Departments of Chemistry and Biochemistry, Vanderbilt-Ingram Cancer Center, Vanderbilt \\ University, Nashville, Tennessee, 37235, United States.
}

\begin{abstract}
The apurinic/apyrimidinic (AP) site is a common lesion of DNA damage. The levels of AP sites reported in the literature range widely, which is primarily due to the artefactual generation or loss of AP sites during processing of the DNA. Herein, we have developed a method to quantitate AP sites with a largely reduced level of artifacts by derivatizing AP sites before DNA isolation. A rapid digestion of nuclear protein was performed to minimize enzymatic DNA repair, followed by direct derivatization of AP sites in the nuclear lysate with $O$-(pyridin-3-yl-methyl)hydroxylamine (PMOA), yielding an oxime derivative that is stable through subsequent DNA processing steps. Quantitation was done using highly selective and sensitive liquid chromatography-tandem mass spectrometry, with a limit of quantitation at 2.2 lesions per $10^{8}$ nucleotides (nts, $0.9 \mathrm{fmol}$ on column). The method was applied in vivo to measure AP sites in rats undergoing oxidative stress [liver: $3.31 \pm 0.47 / 10^{7} \mathrm{nts}$ (dosed) vs $0.91 \pm 0.06 / 10^{7} \mathrm{nts}$ (control), kidney: $1.60 \pm 0.07 / 10^{7} \mathrm{nts}$ (dosed) vs $1.13 \pm 0.12 / 10^{7} \mathrm{nts}$ (control)]. The basal AP level was significantly lower than literature values. The method was also used to measure AP sites induced by the chemotherapeutic nitrogen mustard in vitro.
\end{abstract}

\section{Graphical Abstract}

Exogenously or endogenously induced DNA apurinic/apyrimidinic sites can be quantitated by direct derivatization of nuclei and liquid chromatography-tandem mass spectrometry.

\footnotetext{
* Corresponding Author To whom correspondence should be addressed. Tel: 1-612-626-0141; Fax: 1-612-624-3869;

Rturesky@umn.edu.

Author Contributions

All authors have given approval to the final version of the manuscript.

Supporting Information

The Supporting Information is available free of charge on the ACS Publications website.

PDF: Materials and instrumentation, derivatization of AP sites in oligo, stability of PMOA-labeled AP sites in different buffers, calibration curve of PMOA-dR in CT DNA digest matrix, recovery of PMOA-dR in DNA digestion and SPE, recovery of PMOAderivatized DNA as a function of different enzyme concentrations, stability of free and PMOA-derivatized AP sites during DNA isolation, UV-Vis and NMR spectra of PMOA-dR.

The authors declare no competing financial interest.
} 


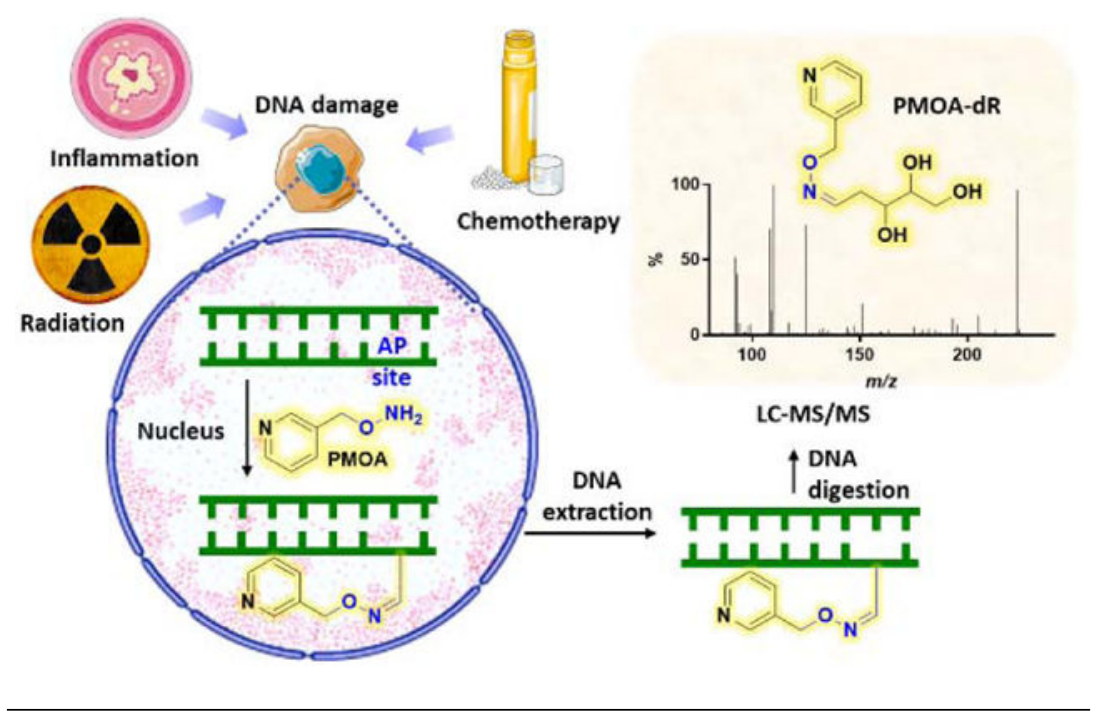

\section{INTRODUCTION}

The apurinic/apyrimidinic (AP) site is a ubiquitous DNA lesion and the central intermediate in DNA base excision repair (BER) pathway. ${ }^{1}$ Various processes, such as alkylation and deamination of bases, oxidative stress, or radiation can lead to damaged DNA bases that are excised by DNA glycosylases and result in AP sites. ${ }^{2-4}$ Spontaneous cleavage of a glycosylic bond also generates AP sites, which happens slowly under physiological conditions but is greatly accelerated by heating or acidic $\mathrm{pH} .{ }^{5}$ The non-coding abasic lesion can be cytotoxic and mutagenic if not efficiently repaired. ${ }^{6-9}$ In mammals, the major pathway for removing this lesion utilizes an AP endonuclease to incise the 5' end of AP sites, resulting in a $5^{\prime}$ deoxyribose phosphate terminus that is subsequently repaired by DNA polymerase $\beta .{ }^{1,10}$ Isolated AP sites can be rapidly repaired by BER, while clustered lesions can persist in cells for over one day. ${ }^{11,12}$

AP sites exist in several equilibria forms. ${ }^{13,14}$ The aldehyde form can react with alkoxyamine agents and yield a relatively stable oxime. This chemical reaction is often employed as a primary strategy for AP site derivatization and quantitation. Many analytical methods have been developed for quantitating AP sites, including chemiluminescent or fluorescent probes, ${ }^{5,15-20}$ as well as mass spectrometry (MS) techniques. ${ }^{21-24}$ The former strategies, e.g., the commonly used aldehyde-reactive probe (ARP) assay, label all naturally occurring aldehydes and ketones present in DNA non-selectively. In comparison, MS is a more specific method for measuring AP sites where exact mass and product ions are used for an accurate quantitation. ${ }^{19}$

Literature values for the steady-state level of AP sites vary considerably, when assayed by different analytical methods. The ARP assay is a luminescent assay that reacts with aldehydes and ketones via a hydroxylamine group but does not provide further structural information. Oxidative damage to the sugar backbone of DNA leads to strand breaks that leave reactive aldehyde and ketone group on the remnants of the deoxyribose. ${ }^{25}$ The steadystate level of ARP reactive DNA lesions (including AP sites) has been estimated to range 
from $<0.67$ AP sites $/ 10^{6}$ nucleotides (nts) in human cell lines to $\sim 1 \mathrm{AP}$ sites $/ 10^{5} \mathrm{nts}$ in mammalian tissues. ${ }^{12,15,26}$ A recently developed liquid chromatography-tandem mass spectrometry (LC-MS/MS) method estimated that the steady-state level of AP sites was $\sim 1$ AP site $/ 10^{6}$ nts in cell lines. ${ }^{24}$ The wide discrepancies in reported values of AP sites are likely due to the artifactual formation or the loss of AP sites during DNA isolation, digestion, or the derivatization step.

We surmise that the actual level of AP sites is considerably lower than reported. In this paper, we describe a method for quantitating AP sites in nuclear DNA isolated from mammalian tissue with reduced artifact formation. Our approach is to isolate the nuclei from tissue homogenate and immediately deactivate most BER enzymes with proteinase $\mathrm{K}$ digestion. The nuclear DNA is then derivatized with $O$-(pyridin-3-yl-methyl)hydroxylamine (PMOA) in the nuclear lysate matrix (Scheme 1). The alkoxyamine modified DNA is isolated, enzymatically digested, and measured by LC-MS/MS.

The method was applied to measure oxidative stress and nitrogen mustard alkylation induced-AP site generation in vivo and in vitro. In a rat model, ferric nitrilotriacetate (FeNTA)-mediated oxidative stress leads to an over three-fold increase of AP sites. The induction of AP site formation in isolated DNA followed a linear relationship to the concentration of the chemotherapeutic nitrogen mustard.

\section{MATERIAL AND METHODS}

\section{Caution:}

Fe-NTA and $N, N$-bis(2-chloroethyl)ethylamine (NM) are carcinogens and must be handled in a well-ventilated fume hood with proper use of gloves and protective clothing. All reagents and instrumentation information are reported in supporting information.

\section{Optimizing the derivatization efficiency of PMOA with AP sites in oligonucleotides}

The experiments conducted with a single-stranded oligonucleotide are reported in supporting information. AP sites were prepared by uracil DNA glycosylase-catalyzed removal of uracil in double-stranded ( $5^{\prime}$-GCCGTUAGGTA-3' • 3'-CGGCAATCCAT-5') oligonucleotide. $^{22}$ The oligonucleotide was reacted with $5 \mathrm{mM}$ PMOA at $37{ }^{\circ} \mathrm{C}$ at $\mathrm{pH} 7.0$ without a catalyst, or at $\mathrm{pH} 7.4$ with 5 or $10 \mathrm{mM} \mathrm{L-histidine.}$

To explore the catalytic effect of enzymes, the double-stranded 11-mer oligonucleotide (50 $\mu \mathrm{L}, 1.89 \mu \mathrm{g} / \mu \mathrm{L})$, RNase A (15 $\mu \mathrm{L}, 150 \mu \mathrm{g})$, and RNase $\mathrm{T}_{1}(1 \mu \mathrm{L}$, Sigma R1003) were added to $500 \mu \mathrm{L}$ of TE buffer [ $50 \mathrm{mM}$ Tris-HCl buffer, $10 \mathrm{mM}$ ethylenediaminetetraacetic acid (EDTA), pH 8.0]. PMOA ( $25 \mu \mathrm{L}, 100 \mathrm{mM}$ in water) was added and incubated for $30 \mathrm{~min}$ at $37^{\circ} \mathrm{C}$. Then, proteinase $\mathrm{K}(20 \mu \mathrm{L}, 400 \mu \mathrm{g})$ was added and incubated for another $30 \mathrm{~min}$. Finally, Puregene Protein Precipitation (PP) solution ( $250 \mu \mathrm{L}, \mathrm{pH}=8$, Qiagen) was added, and the mixture was incubated for an additional $30 \mathrm{~min}$. At selected time points, aliquots were taken, and the unreacted oligonucleotide was quantitated with HPLC-UV at $260 \mathrm{~nm}$. 


\section{Synthesis of $(3 S, 4 R)-3,4,5$-trihydroxypentanal O-pyridin-3-yl-methyl oxime (PMOA-dR) and $\left[{ }^{13} C_{5}\right]$-PMOA-dR.}

PMOA ( $20 \mathrm{mg}, 0.16 \mathrm{mmol}$ ) was added to $500 \mu \mathrm{L}$ of $50 \mathrm{mM}$ potassium phosphate buffer (pH 7.0) containing 2-deoxy-D-ribose $(23 \mathrm{mg}, 0.17 \mathrm{mmol})$ and incubated in a thermomixer at $37^{\circ} \mathrm{C}$ for $1 \mathrm{~h}$. The product was purified by HPLC (Agilent 1260 Infinity HPLC), with mobile phases (A) $5 \mathrm{mM}$ ammonium bicarbonate $(\mathrm{pH}=7.8)$ and (B) methanol. An XBridge Prep Phenyl column $(10 \times 250 \mathrm{~mm}, 5 \mu \mathrm{m}$ particle size, Waters $)$ was used to separate the compounds at a flow rate of $3 \mathrm{~mL} / \mathrm{min}$ using a $50 \mathrm{~min}$ isocratic flow at $10 \% \mathrm{~B}$. Fractions were collected and dried under high vacuum to yield the two geometric isomers as white solids.

Overall product yield: $92 \%$. Yield of $Z$ isomer: $16.8 \mathrm{mg}$. UV extinction coefficient at $260 \mathrm{~nm}$ $\left(2 \mathrm{mM} \mathrm{NH}_{4} \mathrm{HCO}_{3}\right): \mathcal{\varepsilon}=2.84 \times 10^{3} \mathrm{M}^{-1} \cdot \mathrm{cm}^{-1}$. Yield of $E$ isomer: $18.5 \mathrm{mg}, \varepsilon=2.87 \times 10^{3} \mathrm{M}$ ${ }^{-1} \cdot \mathrm{cm}^{-1}$. The UV spectra and ${ }^{1} \mathrm{H}-\mathrm{NMR}$ are reported in supporting information. $\left[{ }^{13} \mathrm{C}_{5}\right]-$ PMOA-dR was synthesized using $\left[{ }^{13} \mathrm{C}_{5}\right]$-2-deoxy-D-ribose and purified as an isomeric mixture (isotopic purity $>99.8 \%$ ).

\section{Derivatization of AP sites in isolated DNA.}

Calf thymus (CT) DNA (30 $\mu \mathrm{g}$ ) was incubated at $37{ }^{\circ} \mathrm{C}$ for $1.5 \mathrm{~h}$ in PBS buffer (pH 7.4) containing $5 \mathrm{mM}$ histidine and 0.5 to $20 \mathrm{mM}$ PMOA. The excess PMOA was consumed by adding butyraldehyde solution ( $1 \mathrm{M}$ in 50\% isopropanol/water) to a final concentration of 50 $\mathrm{mM}$ and incubated at $37^{\circ} \mathrm{C}$ for $10 \mathrm{~min}$.

The DNA was precipitated by adding 0.1 volume of $5 \mathrm{M} \mathrm{NaCl}$ and two volumes of chilled isopropanol, washed twice with 70\% ethanol in $5 \mathrm{mM}$ HEPES buffer (pH 8.0), and dried under vacuum centrifugation. The DNA pellet was reconstituted in $5 \mathrm{mM}$ HEPES buffer $(\mathrm{pH}$ 8.0), and the concentration was determined by UV assuming that $50 \mu \mathrm{g} / \mathrm{mL}$ of doublestranded DNA is equal to an absorbance of 1.0 at $260 \mathrm{~nm}$.

\section{Enzymatic digestion of AP sites in DNA.}

The $\left[{ }^{13} \mathrm{C}_{5}\right]$-PMOA-dR (stable isotopically labeled internal standard, 1.1 per $10^{6} \mathrm{nt}$ ) was added to the DNA prior to enzymatic digestion. The DNA samples $(28 \mu \mathrm{g})$ were incubated at $37{ }^{\circ} \mathrm{C}$ with DNase I ( $\left.5 \mu \mathrm{g}\right)$ and nuclease $\mathrm{P}_{1}(0.5 \mu \mathrm{g})$ for $3 \mathrm{~h}$, followed by phosphodiesterase I $(0.25 \mu \mathrm{g})$ and alkaline phosphatase $(2 \mu \mathrm{g})$ for $15 \mathrm{~h}$, and then incubated with adenosine deaminase $(12 \mathrm{mU})$ at $25^{\circ} \mathrm{C}$ for $1.5 \mathrm{~h}$.

\section{Solid phase extraction method (SP) method.}

After DNA digestion, the derivatized AP sites were enriched by solid phase extraction (SPE) with a Strata-X polymeric cartridge ( $30 \mathrm{mg}, 33 \mu \mathrm{m}$ ) preconditioned with $\mathrm{CH}_{3} \mathrm{OH}$, followed by $\mathrm{H}_{2} \mathrm{O}$. The cartridge was washed with $8 \% \mathrm{CH}_{3} \mathrm{OH}$ in $2 \mathrm{mM} \mathrm{NH}_{4} \mathrm{HCO}_{3}(2.5 \mathrm{~mL})$, and the PMOA-dR was eluted from the cartridge with $90 \% \mathrm{CH}_{3} \mathrm{OH}$ in $2 \mathrm{mM} \mathrm{NH}_{4} \mathrm{HCO}_{3}(1 \mathrm{~mL})$. The eluents were dried by vacuum centrifugation, reconstituted in $20 \mu \mathrm{L} 2 \mathrm{mM} \mathrm{NH}_{4} \mathrm{HCO}_{3}$, and transferred to LC autosampler vials for LC-MS/MS analysis. 


\section{LC-MS/MS method for quantitation of PMOA-dR in DNA.}

Quantitation of PMOA-dR was conducted on a Velos Pro ion-trap mass spectrometer (Thermo Fisher Scientific, San Jose, CA) equipped with an UltiMate ${ }^{\text {TM }} 3000$ RSLCnano System (Thermo Fisher Scientific, San Jose, CA) and an Advance CaptiveSpray source (Michrom bioresource Inc., Auburn, CA). A Magic C18AQ reversed-phase column (Michrom Bioresources, Inc., $0.3 \times 150$ mm, $3 \mu \mathrm{m}$ particle size, $100 \AA$ A pore size) was employed for chromatographic separation. The solvents that constitute the mobile phases were (A) $2 \mathrm{mM} \mathrm{NH}_{4} \mathrm{OAc}$ and (B) $2 \mathrm{mM} \mathrm{NH}_{4} \mathrm{OAc}$ in $95 \% \mathrm{CH}_{3} \mathrm{CN}$. The sample $(9 \mu \mathrm{L})$ was injected onto the analytical column with the following gradient elution profile: $0-2 \mathrm{~min}: 5$ $\mu \mathrm{L} / \mathrm{min}, 1 \% \mathrm{~B} ; 2-2.5 \mathrm{~min}: 5-2 \mu \mathrm{L} / \mathrm{min}, 1 \% \mathrm{~B} ; 2.5$ to $20 \mathrm{~min}: 2 \mu \mathrm{L} / \mathrm{min}, 1$ to $95 \% \mathrm{~B} ; 20-22$ min: $2-5 \mu \mathrm{L} / \mathrm{min}, 95 \% \mathrm{~B} ; 22-24 \mathrm{~min}: 5 \mu \mathrm{L} / \mathrm{min}, 95-1 \% \mathrm{~B}, 24-30 \mathrm{~min}: 5 \mu \mathrm{L} / \mathrm{min}, 1 \% \mathrm{~B}$. Under this condition, the $E$ and $Z$ isomers of PMOA-dR coelute as a single peak. PMOA-dR was quantified in the positive ion mode. MS/MS parameters were as follows: collisioninduced dissociation (CID): $30 \%$, activation Q: 0.25 , isolation width: 2.0 . PMOA-dR ( $\mathrm{m} / \mathrm{z}$ $241.1 \rightarrow 92.0,108.0,110.0,125.0) ;\left[{ }^{13} \mathrm{C}_{5}\right]-\mathrm{PMOA}-\mathrm{dR}(\mathrm{m} / \mathrm{z} 246.1 \rightarrow 92.0,108.0,110.0$, 125.0).

A seven-point calibration curve was constructed with a CT DNA digestion matrix. The DNA was digested and cleaned up with SPE as described above, then the internal standard $\left[{ }^{13} \mathrm{C}_{5}\right]-$ PMOA-dR was spiked at $100 \mathrm{fmol} / 30 \mu \mathrm{g}$ DNA (1.1 per $\left.10^{6} \mathrm{nts}\right)$, together with the synthesized PMOA-dR standard (1:1 isomeric mixture). The calibration curve ranged from $0,0.22$, up to 275 PMOA-dR per $10^{7}$ and contained three replicates per calibrant level. The lower limit of quantitation (LLOQ) was $0.9 \mathrm{fmol}$ of derivatized AP-site on column, or 2.2 PMOA-dR adducts per $10^{8} \mathrm{nts}$ in $13.5 \mu \mathrm{g}$ of enzymatically digested CT DNA serving as the background matrix. The calibration curve was fitted with linear least-square regression analysis using 1/y weighting with GraphPad Prism software (V 6), $\mathrm{R}^{2}=0.9989$ (Figure S4).

\section{Animal studies.}

All protocols were reviewed and approved by the University of Minnesota Institutional Animal Care and Use Committee.

Fe-NTA was prepared according to reported method ${ }^{27,28}$ with modifications. $\mathrm{Fe}\left(\mathrm{NO}_{3}\right)_{3}(1$ M, $5 \mathrm{~mL})$ was mixed with $\mathrm{HCl}(1 \mathrm{~N}, 5 \mathrm{~mL})$ and $\mathrm{Na}_{2}-\mathrm{NTA}(1 \mathrm{M}, 10 \mathrm{~mL})$. The $\mathrm{pH}$ was adjusted to 7.4 with $\mathrm{Na}_{2} \mathrm{CO}_{3}(1 \mathrm{M})$ and the volume was increased to $37.5 \mathrm{~mL}$ with Milli-Q water. Final concentration: $133 \mathrm{mM} \mathrm{Fe}(\mathrm{III}), 7.5 \mathrm{mg} \mathrm{Fe} / \mathrm{mL}$. The negative control vehicle was prepared by adding $\mathrm{Na}_{2} \mathrm{CO}_{3}(1 \mathrm{M})$ to $\mathrm{HCl}(1 \mathrm{~N}, 5 \mathrm{~mL})$ to adjust the $\mathrm{pH}$ to 7.4 , and then the volume was increased to $37.5 \mathrm{~mL}$ with Milli-Q water. Male F344 rats aged three months, body weight range 240-266 g (Charles River Laboratories, Wilmington, MA), were housed in the animal facility under standard conditions on AIN-76A diet. After one week of acclimatization, the rats were dosed with vehicle or Fe-NTA at $15 \mathrm{mg} \mathrm{Fe} / \mathrm{kg}$ body wt. via intraperitoneal injection ( $\mathrm{n}=4$ in each group), and sacrificed $6 \mathrm{~h}$ after dosing. ${ }^{29}$ Kidneys and livers were immediately put on dry ice and frozen at $-80{ }^{\circ} \mathrm{C}$ until sample workup. 
For measuring spontaneous depurination rate, as well as AP site induced by DNA alkylation, healthy male F344 rats aged 70 days, body weight 204-218 g, were sacrificed one week after acclimatization.

\section{Derivatization of AP sites in mammalian tissue.}

Step 1. Fresh-frozen rat tissue from Fe-NTA treated and control rats were homogenized with a PRO 200 homogenizer (PRO Scientific, Oxford, CT) in HE lysis buffer [50 mM HEPES buffer, $10 \mathrm{mM}$ EDTA, $\mathrm{pH} 8.0$ ] on ice. The tissue homogenate (40 mg wet weight) was centrifuged at 3,000 $g$ at $4{ }^{\circ} \mathrm{C}$, and the nuclear pellet was resuspended in HE buffer $(500 \mu \mathrm{L})$. Proteinase K $(20 \mu \mathrm{L}, 20 \mathrm{mg} / \mathrm{mL}$ in water) and $10 \%$ SDS $(60 \mu \mathrm{L})$ were added to the suspension and incubated in a thermomixer at $37^{\circ} \mathrm{C}, 900 \mathrm{rpm}$ for $1.5 \mathrm{~h}$. Step 2. (A) Direct derivatization of the nuclear lysate: PMOA ( $32 \mu \mathrm{L}$ of $100 \mathrm{mM}$ stock solution was the optimized concentration and used for the rest of the experiments) was added to the nuclear lysate and incubated at $37^{\circ} \mathrm{C}$ for $1.5 \mathrm{~h}$. Butyraldehyde ( $30 \mu \mathrm{L}, 1 \mathrm{M}$ in $50 \%$ isopropanol/ water) was then added to quench the remaining PMOA by further incubation for $10 \mathrm{~min}$. The samples were kept on ice for $5 \mathrm{~min}$, then $250 \mu \mathrm{L}$ Puregene PP solution was added. The tubes were vortexed thoroughly and centrifuged at 2,000 $\mathrm{g}$ for $10 \mathrm{~min}$. The supernatant was transferred to a new $2 \mathrm{~mL}$ Eppendorf tubes, and the nucleic acid was precipitated with 0.1 volume of $\mathrm{NaCl}(5 \mathrm{M})$ and $1 \mathrm{~mL}$ isopropanol. The pellet was washed with $70 \%$ ethanol in 5 mM HEPES buffer ( $\mathrm{pH}$ 8.0) and dried under vacuum centrifugation. (B) Derivatization of the isolated nucleic acid mixture: proteins were removed with Puregene PP solution, and the nucleic acid pellet was isolated by the method described above. The pellet was reconstituted in PBS buffer ( $\mathrm{pH} 7.4$ ) containing histidine $(5 \mathrm{mM})$ and derivatized with PMOA (as described above) at $37{ }^{\circ} \mathrm{C}$ for $1.5 \mathrm{~h}$, then quenched with butyraldehyde and isolated. Step 3. The derivatized pellets were reconstituted with $300 \mu \mathrm{L} \mathrm{HE}$ buffer, incubated at $37^{\circ} \mathrm{C}$ with RNase A $(150 \mu \mathrm{g})$ and RNase $\mathrm{T}_{1}(0.5 \mu \mathrm{g})$ for $1.5 \mathrm{~h}$, and the enzymes were precipitated with Puregene PP solution. The DNA pellet was isolated, digested, and quantitated by LC-MS/MS as described above.

\section{Determination of spontaneous depurination rate.}

Liver tissue from healthy rats was homogenized, and the isolated nuclear pellet was resuspended in HE buffer $(500 \mu \mathrm{L})$. Proteinase $\mathrm{K}(20 \mu \mathrm{L}, 20 \mathrm{mg} / \mathrm{mL}$ in water) and $10 \%$ SDS $(60 \mu \mathrm{L})$ were added to the suspension and incubated at $37^{\circ} \mathrm{C}$ for $0,1.5,3, \ldots, 47.5 \mathrm{~h}$. After the incubation, PMOA ( $32 \mu \mathrm{L}$ of $100 \mathrm{mM}$ stock solution) was added to the nuclear lysate and incubated at $37^{\circ} \mathrm{C}$ for $1.5 \mathrm{~h}$, then the reaction was quenched with butyraldehyde, and the DNA was isolated and quantitated as described in method A.

\section{Artifactual formation of AP sites during sample workup.}

Liver tissue from healthy rats was homogenized, and the isolated nuclear pellet was resuspended in HE buffer $(500 \mu \mathrm{L})$. The AP sites were derivatized under four conditions. Method A: Derivatization was performed in the nuclear lysate after proteinase K digestion, as described in method A. A1: Immediately after nuclei isolation, proteinase $\mathrm{K}(20 \mu \mathrm{L}, 20$ $\mathrm{mg} / \mathrm{mL}$ in water), $10 \%$ SDS $(60 \mu \mathrm{L})$, as well as PMOA (32 $\mu \mathrm{L}$ of $100 \mathrm{mM}$ stock solution) were added to the suspension, incubated at $37^{\circ} \mathrm{C}$ for $1.5 \mathrm{~h}$, and quenched with 
butyraldehyde. The derivatized DNA was then isolated as described in method A. A2: The nuclear pellet suspension was treated with the same amount (as method A) of RNase A and RNase $\mathrm{T}_{1}$ for $1.5 \mathrm{~h}$, followed by proteinase $\mathrm{K}$ and SDS for $2 \mathrm{~h}$. Puregene PP solution was added to precipitate the proteins, and the DNA in the supernatant was precipitated with $\mathrm{NaCl}$ and chilled isopropanol, washed twice, and dried under vacuum. The isolated pellet was incubated in PBS buffer ( $200 \mu \mathrm{L}, \mathrm{pH} 7.4)$ containing histidine ( $5 \mathrm{mM})$ and PMOA $(5 \mathrm{mM})$ at $37{ }^{\circ} \mathrm{C}$ for $1.5 \mathrm{~h}$ and the reaction was quenched with butyraldehyde. The derivatized DNA was precipitated, washed twice and dried under vacuum. A3: The nuclear lysate was treated with the same enzymes and reagents in method A2 except that the DNA pellet was precipitated under $-20{ }^{\circ} \mathrm{C}$ overnight before derivatization. The AP sites were quantitated by LC-MS/MS as described above.

\section{Quantitation of NM-induced AP sites in isolated DNA.}

Nuclear DNA was isolated from fresh-frozen untreated rat liver tissue. Briefly, after tissue homogenization on ice, the nuclear pellet was immediately digested with proteinase $\mathrm{K}$ and SDS, and the nucleic acid was isolated with Puregene solution. RNase $\mathrm{A} / \mathrm{T}_{1}$ digestion was performed, and the DNA pellet was isolated as described above. DNA $(42 \mu \mathrm{g})$ was incubated in $500 \mu \mathrm{L}$ PBS buffer ( $\mathrm{pH} 7.4)$ containing freshly prepared $N, N$-Bis(2chloroethyl)ethylamine (nitrogen mustard, NM) at $0,3,10,30$, or $100 \mu \mathrm{M}$ at $37^{\circ} \mathrm{C}$ for $1 \mathrm{~h}$. The excess NM was removed with ethyl acetate extraction $(500 \mu \mathrm{L} \times 3)$. The DNA was precipitated, washed twice with ethyl acetate, and dried. The DNA was reconstituted in 450 $\mu \mathrm{L}$ PBS buffer ( $\mathrm{pH} 7.4$ ) and incubated at $37{ }^{\circ} \mathrm{C}$ for $5 \mathrm{~h}$ to induce AP sites derived from N7alkylated guanine adducts. ${ }^{30}$ The AP sites were then derivatized by adding histidine $(5 \mathrm{mM})$ and PMOA (5 mM), and then quantitated by LC-MS/MS as described above.

\section{RESULTS AND DISCUSSION}

\section{Optimization of PMOA derivatizing efficiency using oligonucleotides}

We employed AP site-containing 11-mer oligonucleotides to optimize the derivatization reaction. Enzymatic removal of uracil in single- and double-stranded oligonucleotides quantitatively generated a single AP site per oligonucleotide. ${ }^{22}$ We chose the commercially available $O$-(pyridin-3-yl-methyl)hydroxylamine (PMOA) as the derivatization agent due to its product stability, ${ }^{31}$ moderate polarity, and the basic pyridine nitrogen enhances ionization efficiency.

The derivatization reaction with both the single- and double-stranded oligonucleotide was completed within $3 \mathrm{~h}$ at $\mathrm{pH} 7.0$ and $37^{\circ} \mathrm{C}$, as measured by HPLC-UV (Figure S1/S2). The efficiency of the reaction largely depends on $\mathrm{pH}$. Since oxime formation is an acid-catalyzed reaction, ${ }^{16,32}$ a lower $\mathrm{pH}$ gives a faster derivatization rate (Figure $1 \mathrm{~A}$, the reaction was completed within $3 \mathrm{~h}$ at $\mathrm{pH} 7.0$ vs. $4 \mathrm{~h}$ at $\mathrm{pH}$ 7.4). Nevertheless, lower $\mathrm{pH}$ also promoted oxime hydrolysis (reverse reaction of oxime formation), as well as spontaneous depurination that generates artifactual AP sites. ${ }^{33,34}$ The PMOA-derivatized oligonucleotides hydrolyzed at $\mathrm{pH} 7.1(15 \%)$ or $\mathrm{pH} 7.6(5 \%)$ at $37{ }^{\circ} \mathrm{C}$ over $24 \mathrm{~h}$, while the derivatized AP site was completely stable at $\mathrm{pH} 8.0$ (Figure $\mathrm{S} 3$ ). Therefore, all buffers used after the derivatization reaction were kept at $\mathrm{pH} \geq 8.0$ to minimize hydrolytic loss. 
We utilized histidine as a catalyst to optimize the PMOA derivatization reaction with an APsite containing oligonucleotide duplex. The reaction was conducted at $\mathrm{pH} 7.4$ and thus, minimized the hydrolysis of glycosidic bonds and formation of artefactual AP-site. ${ }^{33,34}$ The addition of $5 \mathrm{mM}$ histidine ${ }^{35}$ reduced the derivatization time from 4 to $1.5 \mathrm{~h}$. A further increase of the histidine concentration only slightly enhanced the efficiency of the reaction (Figure 1A). We then tested the PMOA derivatization reaction in the presence of the reagents required to process cellular DNA. We reacted PMOA with AP-containing duplex oligonucleotide in TE buffer at $37{ }^{\circ} \mathrm{C}$ in the presence of RNases for $30 \mathrm{~min}$, then added proteinase K, followed by the Puregene PP solution (Figure 1A, triangles, and grey lines). Interestingly, the rate of derivatization increased after addition of proteinase K. Although we did not investigate the exact mechanism, we suspect the digestion of proteins generates sufficient quantities of amino acids to serve as acid/base catalysts that increase the reaction efficiency. This observation provides another choice of conditions for derivatization of the AP sites in nuclear lysate before DNA isolation, which we have investigated in the following experiments.

\section{LC-MS/MS method to quantitate AP sites}

An LC-MS/MS method was developed with the Velos Pro ion-trap mass spectrometer monitoring at the $\mathrm{MS}^{2}$ scan stage. The collision-induced dissociation (CID) of PMOA-dR and $\left[{ }^{13} \mathrm{C}_{5}\right]$-PMOA-dR produced product ions at $\mathrm{m} / \mathrm{z} 92,108,110,125$, which were extracted for identification and quantitation of the AP site (Figure 2). The LLOQ value was $0.9 \mathrm{fmol}$ of derivatized AP-site, or 2.2 PMOA-dR adducts per $10^{8} \mathrm{nts}$ in $13.5 \mu \mathrm{g}$ of DNA assayed on column.

\section{Stability and recovery of PMOA-dR DNA during enzymatic digestion and SPE processing}

The stability of the derivatized AP-site during nuclease digestion of the DNA and SPE processing was determined by comparing the peak area ratio (PAR) of PMOA-dR/ $\left[{ }^{13} \mathrm{C}_{5}\right]-$ PMOA-dR in samples spiked with PMOA-dR after DNA digestion/SPE with the PAR of samples spiked with PMOA-dR prior to DNA digestion/SPE, where the internal standard was spiked after DNA digestion/SPE. The average recovery at three concentration levels $\left(0.66,5.5,27.5\right.$ PMOA-dR per $10^{7} \mathrm{nts}$ ) was $108 \pm 7 \%$ (Table S1), indicating no significant loss of PMOA-dR occurred during the processing or enzymatic digestion of DNA. Moreover, we varied the quantity of the four nucleases by 4-fold $(0.5 \mathrm{x}, 1 \mathrm{x}$ or $2 \mathrm{x}$ amounts of all enzymes) to digest PMOA-dR-modified DNA (Figure S5). The level of PMOA-dR recovered from DNA was constant as a function of enzyme concentration, demonstrating that the PMOA labeling did not compromise the efficacy of nuclease digestion of DNA.

\section{Derivatization of AP sites in calf thymus DNA}

We determined the derivatization efficiency of AP sites in CT DNA by reacting PMOA at $37^{\circ} \mathrm{C}, \mathrm{pH} 7.4$, in the presence of $5 \mathrm{mM}$ histidine catalyst. After incubation for $1.5 \mathrm{~h}$, butyraldehyde ${ }^{32}$ was added to quench the reaction, followed by DNA precipitation, digestion, and SPE before LC-MS/MS analysis (Figure 1B). We found that $5 \mathrm{mM} \mathrm{PMOA}$ is sufficient to derivatize all AP sites within $1.5 \mathrm{~h}$. Therefore, we used this concentration of PMOA to derivatize isolated nucleic acids as described below. 


\section{Stability of free and derivatized AP sites during DNA isolation}

Artifactual formation or loss of AP sites during DNA isolation are likely factors for the large discrepancies of AP site levels reported in the literature. Potential sources of artifacts include BER enzyme activity, spontaneous depurination at high temperature and/or low $\mathrm{pH}, \beta$ elimination, and reaction of the AP site with nucleophiles in the DNA isolation matrix. Commercial CT DNA contains a high level of free AP sites ( 1 to 2 AP site/ $10^{5}$ nts, vide supra), which was used as a model to test the AP site stability during DNA isolation. We observed a large variation and relative decrease of free AP site levels, when underivatized CT DNA was processed in the presence of DNA isolation buffers (containing Tris or HEPES, EDTA, ammonium sulfate, Puregene PP solution, isopropanol, etc.) and enzymes (RNases and proteinase K), (Figure S6). In contrast, the PMOA-derivatized CT DNA was highly stable when subjected to the entire DNA isolation process with an average recovery of $93 \pm 3 \%$ derivatized AP sites compared to control group (no incubation performed) (Figure S7 \& Table S2). The stability of AP sites is largely increased upon PMOA labeling because the derivatized oxime structure is less susceptible to potential reactions than the free AP sites with nucleophiles.. Therefore, to control artifacts in AP site quantitation in mammalian tissue samples, we performed the derivatization step before the isolation of DNA.

\section{Derivatization of AP sites in mammalian tissue}

The AP site quantitation method for mammalian tissue was optimized using fresh-frozen tissue of rats treated with Fe-NTA, an iron complex that catalytically generates reactive oxygen species (ROS). ${ }^{36}$ Increased ROS production leads to oxidative stress, which plays an essential role in Fe-NTA-mediated renal and hepatic tumor promotion after long-term administration. ${ }^{37-39}$ Oxidative stress induces DNA lesions that are primarily repaired by BER enzymes, leading to elevated levels of AP sites as the major BER intermediate., 40,41 Therefore, the derivatization method was optimized using both the Fe-NTA-treated and control rats.

Ames and co-workers reported a method for in situ derivatization of AP sites designed to reduce artifact. ${ }^{12}$ They directly derivatized the aldehydic lesions with ARP in the nuclei of living cells, thoroughly washed the cells, and then isolated the DNA for quantitation. Although this strategy largely reduced artifacts from DNA isolation (they reported $₫ 0.67$ AP sites per $10^{6} \mathrm{nts}$ as the steady-state level), the BER enzymes that catalyze the generation or excision of AP sites during derivatization were not completely inhibited. The authors observed more than a three-fold increase of aldehydic lesion when derivatizing the intact nuclei compared to lysed nuclei, where the nuclear glycosylases were released. Thus, herein, to minimize the BER enzyme activity, we immediately digested the nuclear proteins with proteinase $\mathrm{K}$ and SDS after isolating nuclei from rat tissue homogenate. Following proteinase $\mathrm{K}$ treatment for $1.5 \mathrm{~h}$, we compared the efficiency of two derivatization methods: (A) directly adding PMOA to the nuclear lysate to derivatize the AP sites in the presence of proteinase $\mathrm{K}$ at $\mathrm{pH} 8.0$; and (B) quickly precipitating proteins with Puregene PP solution, isolating the nucleic acids, and derivatizing with PMOA under $\mathrm{pH}$ 7.4. After quenching the reaction with excess butyraldehyde, for both method $\mathrm{A}$ and $\mathrm{B}$, the derivatized nucleic acids were then treated with RNases to obtain pure DNA. As mentioned previously, the addition 
of proteinase $\mathrm{K}$ accelerated the rate of PMOA derivatization rate (Figure 1A). Indeed, the rate of derivatization of the nuclear lysate was similar to that of isolated nucleic acids (Figure 3A). The product yield of AP sites reached a plateau at $5 \mathrm{mM}$ PMOA, signifying the reaction went to completion. The AP site level obtained by the two methods is the same, suggesting that the nuclear lysate matrix did not inhibit the efficiency of the reaction. Since the nucleic acid derivatization (method $\mathrm{B}$ ) requires additional isolation steps, we chose the nuclear lysate derivatization (method A) with $5 \mathrm{mM}$ PMOA for quantitation of AP sites in mammalian tissue.

\section{Precision of the method}

The within-day and between-day precision of method A were determined using livers of four Fe-NTA treated rats and four control rats (treated with vehicle). Derivatization, isolation, and quantitation were performed with three independent analyses per animal per day on three different days. The average within-day/between-day coefficient of variation (CV) were $8.6 \% / 9.8 \%$ for the Fe-NTA treated rats, and $8.9 \% / 12.5 \%$ for the control rats (Table 1).

\section{AP-site formation in rats under oxidative stress conditions}

The AP site levels in liver and kidney of Fe-NTA treated and control rats $(\mathrm{n}=4$ for each group) were quantitated using method A and plotted in Figure 3B. As expected, the level of AP sites increased in both organs of Fe-NTA treated rats.. In rat liver, the AP sites of FeNTA-dosed group $\left(3.31 \pm 0.47\right.$ AP sites per $\left.10^{7} \mathrm{nts}\right)$ was almost four-fold higher compared to control group $\left(0.91 \pm 0.06 / 10^{7} \mathrm{nts}\right)$. In rat kidney, dosed group also showed an elevated AP site level (1.60 $\left.\pm 0.07 / 10^{7} \mathrm{nts}\right)$ compared to control group $\left(1.13 \pm 0.12 / 10^{7} \mathrm{nts}\right)$, although the difference was not as large as for liver. The lower level of AP-sites in kidney of Fe-NTA treated rats could be due to its faster AP site repair activity. The repair rate of 8-oxodeoxyguanosine $6 \mathrm{~h}$ after treatment of Fe-NTA was reported to be much faster in rat kidney than in liver. ${ }^{42}$

\section{Determination of spontaneous depurination rate of DNA}

Using our optimized nuclear lysate derivatization method that minimized artifact formation, we observed a background level of AP sites ( $<1 \mathrm{AP}$ site $/ 10^{7} \mathrm{nts}$ in rat livers) that was significantly lower than literature values employing the ARP assay after DNA isolation (8-9 per $10^{6} \mathrm{nts}$ in rat livers). ${ }^{15}$ Our LC-MS/MS method is selective for the quantitation of AP sites, whereas the ARP assay is likely detecting a wider range of aldehydic sites in DNA. However, at this low level of AP site formation, we must consider the spontaneous rate of depurination as an artifact during nuclei-lysis and AP site derivatization. Although the rate of glycosidic bond hydrolysis is low at near-neutral $\mathrm{pH}, 33,34$ the rate of AP site formation in isolated DNA was reported to be $0.64 / 10^{7} \mathrm{nts} / \mathrm{h}$ at $37^{\circ} \mathrm{C}$ at $\mathrm{pH} 7.4$, which is sufficiently high to introduce artifacts. ${ }^{5}$ Herein, we examined the spontaneous generation of regular AP sites in healthy (no treatment performed) rat liver DNA, which was incubated in the nuclear lysate containing proteinase K, SDS, and HE buffer ( $\mathrm{pH} 8.0$ ). As shown in Figure 3C, the AP sites increased linearly at $0.29 / 10^{7} \mathrm{nts} / \mathrm{h}$ during the first $7 \mathrm{~h}$. Then the rate was accelerated during the overnight incubation, which may be attributed to the diffusion of DNA to the lysate buffer following proteolysis of the histones. A linear regression curve- 
fitting of the first $7 \mathrm{~h}$ gave a Y-intercept of $0.50 / 10^{7} \mathrm{nts}$ (Figure 3C), providing an estimate of the background AP site level in healthy male rat liver. Therefore, considering this spontaneous depurination rate, the difference in the AP site level between Fe-NTA and vehicle-treated rats is likely greater than the actual values measured.

\section{Artefactual formation of AP sites during sample workup}

Although the spontaneous depurination is not completely inhibited, this optimized method A greatly reduces the artefactual AP site generation. We compared several different methods of DNA isolation and derivatization. If the nuclear pellet is simultaneously subjected to protein digestion and derivatization, the sample processing time can be shortened by $1.5 \mathrm{~h}$, and the AP site level we obtained is slightly lower (Figure 3D, method A1). However, we cannot confirm whether the derivatization process is complete or if the incomplete digestion of histones restricted the accessibility of PMOA to react with some AP sites.

We also measured the AP site level in DNA isolated by conventional sample processing methods. The RNA in the nuclear pellet was first digested for 1.5 hours, followed by digestion of the protein for 2 hours, precipitation of protein, and salt/isopropanol precipitation of DNA. The DNA precipitation step can be done quickly (method A2) or incubated at $-20^{\circ} \mathrm{C}$ overnight (method A3). As shown in Figure 3D, conventional DNA isolation followed by derivatization resulted in a high level of artifacts. If the precipitated DNA is rapidly derivatized, the AP site level obtained is over two times of that obtained by method A. If the DNA is precipitated overnight before derivatization, the AP site level dropped due to the instability of underivatized AP site. In summary, method A minimizes the artifact formation for quantitation of the AP site in mammalian tissue.

\section{Quantitation of NM-induced AP-sites in isolated DNA}

We applied our method to measure AP site formation in vitro using rat liver DNA alkylated with nitrogen mustard(NM). The reactive intermediates of NM are $N$-alkylaziridinium ions, which react with the nucleophilic nitrogens on DNA bases, yielding mono-DNA adducts and crosslinks. ${ }^{43}$ The NM forms adducts at the endocyclic nitrogen atoms of nucleobases, such as $N 7$ of guanine This cationic $N 7$-guanine (NM-G) adduct readily undergoes depurination. ${ }^{43} .{ }^{43}$ We previously quantitated NM-DNA adducts for the reaction of CT DNA with $1 \mu \mathrm{M}$ $\mathrm{NM}$, yielding monomeric NM-G at 2 adducts $/ 10^{6}$ bases. ${ }^{30}$

We measured the generation of AP sites in isolated DNA treated with a range of NM concentrations. Since AP sites are abundant in CT DNA (vide supra), we used the DNA isolated from livers of healthy untreated rats. The alkylation reaction was performed with $\mathrm{NM}$ and then the AP sites were generated by neutral hydrolysis of $N$-alkylated DNA bases as described in Material and Methods. ${ }^{30}$ Without treatment with NM, the background level of AP sites was estimated at $6.5 \pm 1.5 / 10^{7} \mathrm{nts}$ after neutral hydrolysis; this value was subtracted as the background level from NM-treated DNA. The NM-induced AP sites were plotted against the concentration of NM (Figure 3E), showing an excellent linear doseresponse to the concentration of NM in the range from 3 to $100 \mu \mathrm{M}$. This experiment demonstrates the ability of the assay to quantitate AP sites over a wide range in isolated DNA. 


\section{Summary}

We have developed a sensitive and robust mass spectrometry method for the quantitation of AP sites in DNA and mammalian tissue with minimal artifact formation. The LC-MS/MS method showed a limit of quantitation of $2.2 \mathrm{AP}$ sites per $10^{8} \mathrm{nts}$ for $13.5 \mu \mathrm{g}$ DNA assayed on column with a linearity over three orders of magnitude. By directly derivatizing AP sites in nuclear lysate, the background level of AP sites was significantly reduced compared to literature values. The method was successfully applied in vivo and in vitro to measure the AP site level in liver and kidney of rats undergoing oxidative stress and in isolated DNA damaged by alkylating agents.

\section{Supplementary Material}

Refer to Web version on PubMed Central for supplementary material.

\section{ACKNOWLEDGMENT}

This work is funded by the National Cancer Institute [P01 CA160032], and the National Center for Advancing Translational Sciences of the National Institutes of Health award number UL1TR000114. Mass spectrometry was carried out in the Analytical Biochemistry Shared Resource of the Masonic Cancer Center, University of Minnesota, funded in part by Cancer Center Support [CA 077598].

\section{REFERENCES}

(1). Kim Y-J; Wilson DM Curr. Mol. Pharmacol 2012, 5, 3-13. [PubMed: 22122461]

(2). Lindahl T In Prog. Nucleic Acid Res. Mol. Biol, Cohn WE, Ed.; Academic Press, 1979, pp 135192.

(3). Krokan HE; Standal R; Slupphaug G Biochem. J 1997, 325, 1-16. [PubMed: 9224623]

(4). De Bont R; van Larebeke N Mutagenesis 2004, 19, 169-185. [PubMed: 15123782]

(5). Nakamura J; Walker VE; Upton PB; Chiang S-Y; Kow YW; Swenberg JA Cancer Res. 1998, 58, 222-225. [PubMed: 9443396]

(6). Kingma PS; Corbett AH; Burcham PC; Marnett LJ; Osheroff N J. Biol. Chem 1995, 270, $21441-$ 21444. [PubMed: 7665552]

(7). Boiteux S; Guillet M DNA Repair 2004, 3, 1-12. [PubMed: 14697754]

(8). Kow YW; Bao G; Minesinger B; Jinks-Robertson S; Siede W; Jiang YL; Greenberg MM Nucleic Acids Res. 2005, 33, 6196-6202. [PubMed: 16257982]

(9). Wilson DM; Barsky D Mutat. Res.- DNA Repair 2001, 485, 283-307. [PubMed: 11585362]

(10). Dianov GL; Sleeth KM; Dianova II; Allinson SL Mutat. Res-Fund. Mol. M 2003, 531, 157-163.

(11). Georgakilas AG; Bennett PV; Wilson IIIDM; Sutherland BM Nucleic Acids Res. 2004, 32, 5609_ 5620. [PubMed: 15494449]

(12). Atamna H; Cheung I; Ames BN Proc. Natl. Acad. Sci., U.S.A 2000, 97, 686-691. [PubMed: 10639140]

(13). Lhomme J; Constant J-F; Demeunynck M Biopolymers 1999, 52, 65-83. [PubMed: 10898853]

(14). Wilde JA; Bolton PH; Mazumder A; Manoharan M; Gerlt JA J. Am. Chem. Soc 1989, 111, 1894-1896.

(15). Nakamura J; Swenberg JA Cancer Res. 1999, 59, 2522-2526. [PubMed: 10363965]

(16). Boturyn D; Constant J-F; Defrancq E; Lhomme J; Barbin A; Wild CP Chem. Res. Toxicol 1999, 12, 476-482. [PubMed: 10368309]

(17). Fundador E; Rusling J Anal. Bioanal. Chem 2007, 387, 1883-1890. [PubMed: 17206410]

(18). Kojima N; Takebayashi T; Mikami A; Ohtsuka E; Komatsu Y J. Am. Chem. Soc 2009, 131, 13208-13209. [PubMed: 19754181] 
(19). Liu C; Luo X; Chen Y; Wu F; Yang W; Wang Y; Zhang X; Zou G; Zhou X Anal. Chem 2018, 90, 14616-14621. [PubMed: 30441892]

(20). Wei S; Shalhout S; Ahn Y-H; Bhagwat AS DNA Repair 2015, 27, 9-18. [PubMed: 25616257]

(21). Zhou X; Liberman RG; Skipper PL; Margolin Y; Tannenbaum SR; Dedon PC Anal. Biochem 2005, 343, 84-92. [PubMed: 15964542]

(22). Roberts KP; Sobrino JA; Payton J; Mason LB; Turesky RJ Chem. Res. Toxicol 2006, 19, 300309. [PubMed: 16485907]

(23). Li J; Leung EMK; Choi MMF; Chan W Anal. Bioanal. Chem 2013, 405, 4059-4066. [PubMed: 23423125]

(24). Rahimoff R; Kosmatchev O; Kirchner A; Pfaffeneder T; Spada F; Brantl V; Müller M; Carell T J. Am. Chem. Soc 2017, 139, 10359-10364. [PubMed: 28715893]

(25). Jaruga P Free Radic. Res 2012, 46, 382-419. [PubMed: 22276778]

(26). Barbin A; Ohgaki H; Nakamura J; Kurrer M; Kleihues P; Swenberg JA Cancer Epidemiol. Biomarkers Prevent. 2003, 12, 1241-1247.

(27). Hartwig A; Klyszcz-Nasko H; Schlepegrell R; Beyersmann D Carcinogenesis 1993, 14, 107-112. [PubMed: 8425256]

(28). Toyokuni S; Uchida K; Okamoto K; Hattori-Nakakuki Y; Hiai H; Stadtman ER Proc. Natl. Acad. Sci. U.S.A 1994, 91, 2616-2620. [PubMed: 8146163]

(29). Gautier J-C; Holzhaeuser D; Markovic J; Gremaud E; Schilter B. t. ; Turesky RJ Free Radic. Biol. Med 2001, 30, 1089-1098. [PubMed: 11369498]

(30). Gruppi F; Hejazi L; Christov PP; Krishnamachari S; Turesky RJ; Rizzo CJ Chem. Res. Toxicol 2015, 28, 1850-1860. [PubMed: 26285869]

(31). Kalia J; Raines RT Angew. Chem. Int. Ed 2008, 47, 7523-7526.

(32). Kölmel DK; Kool ET Chem. Rev 2017, 117, 10358-10376. [PubMed: 28640998]

(33). Zoltewicz JA; Clark DF; Sharpless TW; Grahe G J. Am. Chem. Soc 1970, 92, 1741-1750. [PubMed: 5418456]

(34). An R; Jia Y; Wan B; Zhang Y; Dong P; Li J; Liang X PLoS One 2015, 9, e115950.

(35). Larsen D; Pittelkow M; Karmakar S; Kool ET Org. Lett. 2015, 17, 274-277. [PubMed: 25545888]

(36). OKADA S Pathol. Int 1996, 46, 311-332. [PubMed: 8809878]

(37). Toyokuni S Free Radic. Biol. Med 1996, 20, 553-566. [PubMed: 8904296]

(38). Iqbal M; Giri U; Athar M Biochem. Biophys. Res. Commun 1995, 212, 557-563. [PubMed: 7626070]

(39). Kawabata T; Ma Y; Yamador I; Okada S Carcinogenesis 1997, 18, 1389-1394. [PubMed: 9230285]

(40). Nakamura J; La DK; Swenberg JA J. Biol. Chem 2000, 275, 5323-5328. [PubMed: 10681505]

(41). Kryston TB; Georgiev AB; Pissis P; Georgakilas AG Mutat. Res-Fund. Mol. M 2011, 711, $193-$ 201.

(42). Yamaguchi R; Hirano T; Asami S; Chung M-H; Sugita A; Kasai H Carcinogenesis 1996, 17 , 2419-2422. [PubMed: 8968057]

(43). Gates KS Chem. Res. Toxicol 2009, 22, 1747-1760. [PubMed: 19757819] 

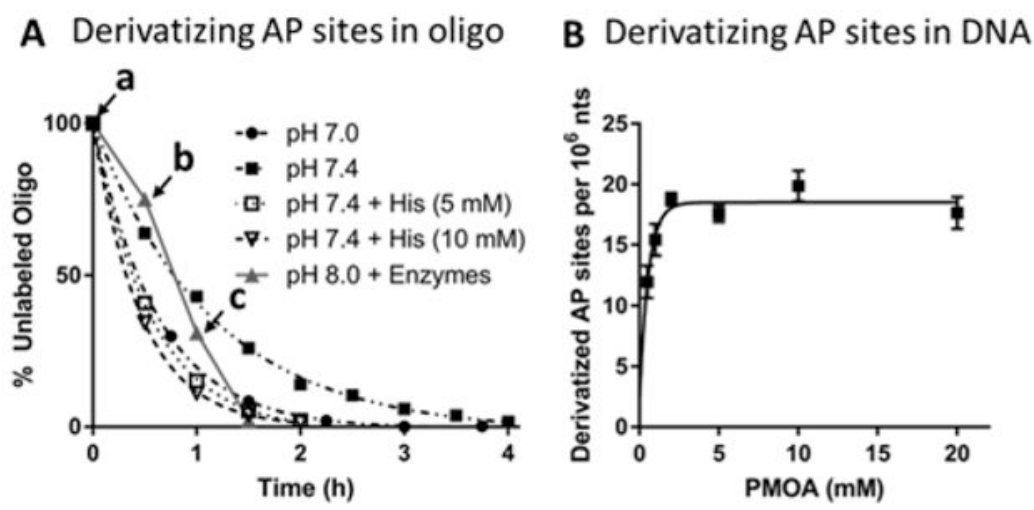

Figure 1.

(A) Derivatization of AP sites in double-stranded oligonucleotide with $5 \mathrm{mM}$ PMOA at $37^{\circ} \mathrm{C}$, with different buffers and catalysts. The percent unreacted oligonucleotide vs. time is reported. Points on the reaction rate curve at $\mathrm{pH} 8.0$ containing sequential addition of enzymes employed during lysis of the nuclear pellet: a. RNase A \& RNase $\mathrm{T}_{1}$ added. b. Proteinase K added, c. Puregene PP solution added, or reactions conducted at $\mathrm{pH} 7.0 \mathrm{or} \mathrm{pH}$ 7.4 without or with histidine. (B) Derivatization of AP sites in CT DNA with various concentrations of PMOA. Reaction condition: $\mathrm{pH} 7.4,37^{\circ} \mathrm{C}, 1.5 \mathrm{~h}$. Each value represents the mean $\pm \mathrm{SD}, \mathrm{n}=3$. 
A

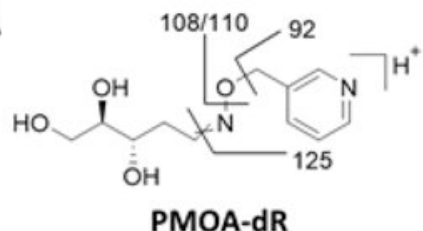

B

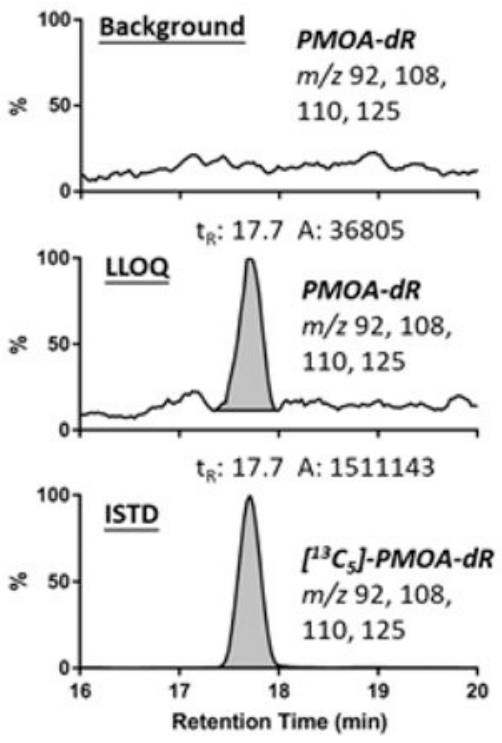

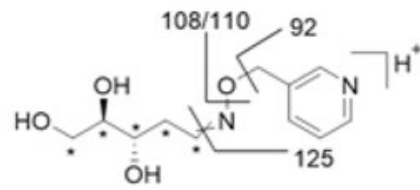

$\left[{ }^{13} C_{5}\right]-P M O A-d R$

C

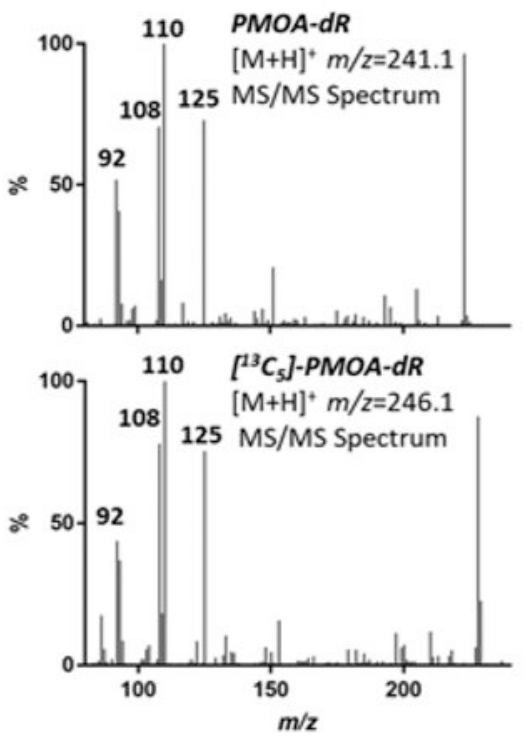

Figure 2.

(A) Proposed MS/MS fragmentation of PMOA-dR $\left([\mathrm{M}+\mathrm{H}]^{+} \mathrm{m} / \mathrm{z} 241.1\right)$ and $\left[{ }^{13} \mathrm{C}_{5}\right]-\mathrm{PMOA}-$ $\mathrm{dR}\left([\mathrm{M}+\mathrm{H}]^{+} \mathrm{m} / \mathrm{z} 246.1\right)$. (B) Extracted ion chromatogram (EIC) of PMOA-dR (at background level normalized against the base peak in LLOQ, and at LLOQ) and $\left[{ }^{13} \mathrm{C}_{5}\right]$ PMOA-dR (1.1 per $\left.10^{6} \mathrm{nts}\right)$ in DNA digestion matrix and (C) PMOA-dR and $\left[{ }^{13} \mathrm{C}_{5}\right]-\mathrm{PMOA}-$ $\mathrm{dR}$ MS/MS spectra. The * represent the sites of the ${ }^{13} \mathrm{C}$ atoms in the internal standard. 
A

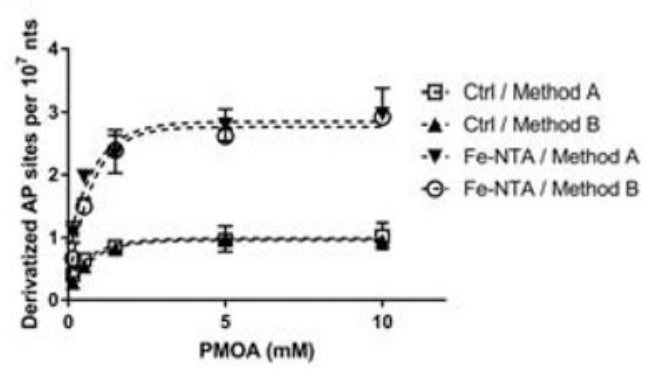

$c$

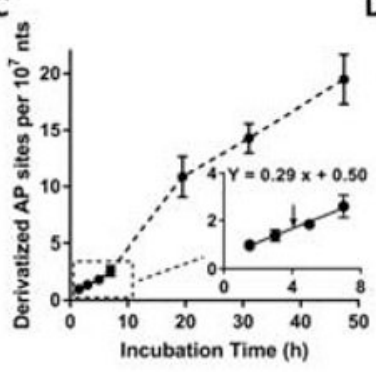

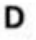

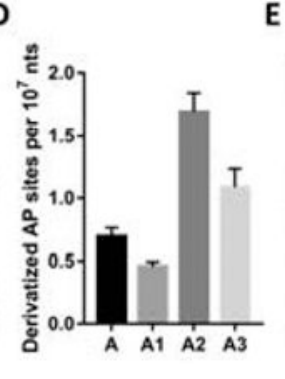

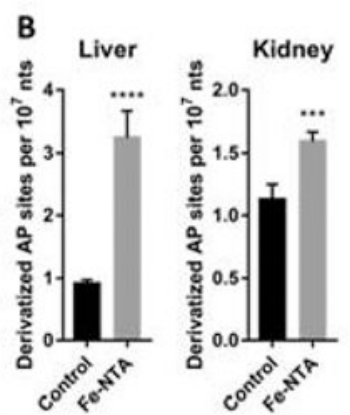

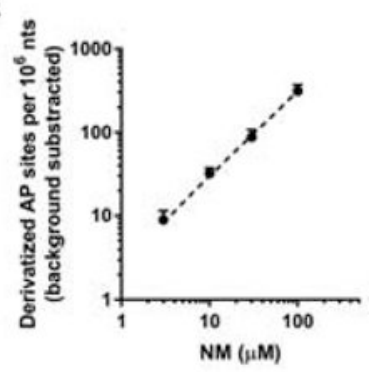

Figure 3.

(A) Derivatization of AP sites in rat liver nuclei. Rats were sacrificed $6 \mathrm{~h}$ after intraperitoneal injection with Fe-NTA (15 mg Fe/kg) and vehicle (Ctrl group). AP sites were derivatized by the nuclear lysate-derivatization method (method A) or nucleic acidderivatization method (method $B$ ). Each value represents the mean $\pm S D, n=3$. (B) AP site level in rat livers and kidneys after administration of Fe-NTA (grey bar) or vehicle (black bar). $\mathrm{n}=4$. Two-tailed t test $\mathrm{p}<0.0001(* * * *), \mathrm{p}<0.001(* * *)$. (C) Spontaneous depurination rate measured in untreated rat liver nuclei lysate $(n=3)$. (D) AP site level in DNA isolated/derivatized by different methods. A. After nuclear isolation, conduct proteolysis for $1.5 \mathrm{~h}$ and then AP site derivatization for $1.5 \mathrm{~h}$. A1: After nuclear isolation, conduct AP site derivatization and proteolysis together for $1.5 \mathrm{~h}$. A2: Treat nuclei with RNases for $1.5 \mathrm{~h}$, proteinase $\mathrm{K}$ for $2 \mathrm{~h}$, and precipitate excess proteins. Precipitate DNA with salt/isopropanol and immediately derivatize the isolated DNA. A3: Unlike method A2, DNA pellet was precipitated under $-20{ }^{\circ} \mathrm{C}$ overnight before derivatization. $n=4$. (E) Isolated rat liver DNA was incubated with $\mathrm{NM}$ at $37^{\circ} \mathrm{C}$ for $1 \mathrm{~h}$, followed by neutral hydrolysis for $5 \mathrm{~h}$ $(\mathrm{pH} 7.4) . \mathrm{n}=3$. The background level of AP sites by neutral hydrolysis $\left(6.5 \pm 1.5 / 10^{7} \mathrm{nts}\right)$ was subtracted. 


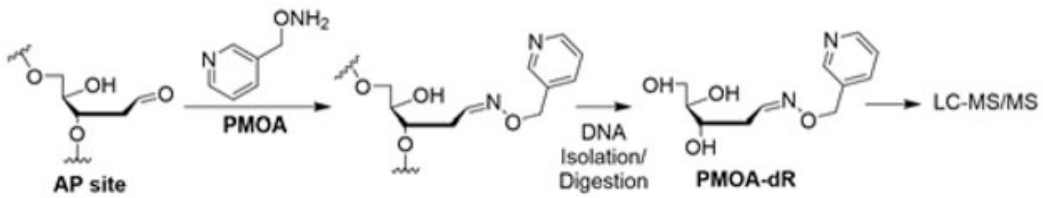

Scheme 1.

Quantitation of AP sites by PMOA derivatizing method. 
Table 1.

Within-day and Between-day Quantitation of AP Sites (per $10^{7}$ nts) in Fe-NTA Treated Rats and Control Rats.

\begin{tabular}{|c|c|c|c|c|c|c|c|c|c|c|c|c|c|}
\hline \multicolumn{7}{|c|}{ Control Rats } & \multicolumn{7}{|c|}{ Fe-NTA Treated Rats } \\
\hline & & \multirow{2}{*}{$\begin{array}{c}\text { Day } \\
1\end{array}$} & \multirow{2}{*}{$\begin{array}{c}\text { Day } \\
2\end{array}$} & \multirow{2}{*}{$\begin{array}{c}\text { Day } \\
\mathbf{3}\end{array}$} & \multirow{2}{*}{$\begin{array}{c}\text { CV\% } \\
\begin{array}{c}\text { Within- } \\
\text { day }\end{array}\end{array}$} & \multirow{2}{*}{$\begin{array}{c}\text { CV\% } \\
\begin{array}{c}\text { Between- } \\
\text { day }\end{array}\end{array}$} & & & \multirow{2}{*}{$\begin{array}{c}\text { Day } \\
1\end{array}$} & \multirow{2}{*}{$\begin{array}{c}\text { Day } \\
2\end{array}$} & \multirow{2}{*}{$\begin{array}{c}\text { Day } \\
\mathbf{3}\end{array}$} & \multirow{2}{*}{$\begin{array}{c}\text { CV\% } \\
\begin{array}{c}\text { Within- } \\
\text { day }\end{array}\end{array}$} & \multirow{2}{*}{$\frac{\mathrm{CV} \%}{\begin{array}{c}\text { Between- } \\
\text { day }\end{array}}$} \\
\hline & & & & & & & & & & & & & \\
\hline & Mean & 0.90 & 1.01 & 0.81 & & & & Mean & 2.86 & 2.77 & 3.04 & & \\
\hline \multirow[t]{3}{*}{1} & SD & 0.01 & 0.11 & 0.12 & 8.9 & 11.3 & 1 & SD & 0.55 & 0.13 & 0.28 & 11.0 & 4.8 \\
\hline & $\mathrm{RSD} \%$ & 1.1 & 10.5 & 14.9 & & & & $\mathrm{RSD} \%$ & 19.1 & 4.8 & 9.2 & & \\
\hline & Mean & 0.78 & 0.88 & 0.81 & & & & Mean & 2.62 & 3.08 & 3.00 & & \\
\hline \multirow[t]{3}{*}{2} & SD & 0.10 & 0.07 & 0.09 & 10.8 & 6.4 & 2 & SD & 0.12 & 0.08 & 0.21 & 4.7 & 8.5 \\
\hline & $\mathrm{RSD} \%$ & 12.9 & 8.5 & 10.9 & & & & $\mathrm{RSD} \%$ & 4.6 & 2.7 & 6.9 & & \\
\hline & Mean & 0.78 & 1.05 & 1.00 & & & & Mean & 3.23 & 4.07 & 3.76 & & \\
\hline \multirow[t]{3}{*}{3} & SD & 0.11 & 0.02 & 0.08 & 8.1 & 15.1 & 3 & SD & 0.19 & 0.28 & 0.15 & 5.6 & 11.6 \\
\hline & $\mathrm{RSD} \%$ & 14.0 & 2.3 & 8.0 & & & & $\mathrm{RSD} \%$ & 6.0 & 6.8 & 3.9 & & \\
\hline & Mean & 0.79 & 1.12 & 0.99 & & & & Mean & 3.16 & 3.86 & 4.22 & & \\
\hline \multirow[t]{2}{*}{4} & SD & 0.09 & 0.09 & 0.04 & 7.8 & 17.4 & 4 & SD & 0.53 & 0.40 & 0.52 & 13.2 & 14.3 \\
\hline & $\mathrm{RSD} \%$ & 10.8 & 8.4 & 4.2 & & & & $\mathrm{RSD} \%$ & 16.9 & 10.4 & 12.3 & & \\
\hline
\end{tabular}

